\title{
Hepatozoon sp. gamonts as an accidental finding in synovial liquid from an injured maned wolf (Chrysocyon brachyurus) in southeastern Brazil
}

Gamontes de Hepatozoon sp. como achado acidental em líquido sinovial de lobo guará (Chrysocyon brachyurus) no sudeste do Brasil

Lívia Perles ${ }^{1}$; Guilherme Henrique Fernandes Barranco ${ }^{1}$; Isabela Maciel Soriano ${ }^{1}$; Nathan da Rocha Neves Cruz²; Patrícia Jábali Bueno ${ }^{2}$; Âureo Evangelista Santana ${ }^{2}$; Rosangela Zacarias Machado ${ }^{1}$; Karin Werther ${ }^{1}$; Marcos Rogério André ${ }^{*}$

${ }^{1}$ Departamento de Patologia Veterinária, Universidade Estadual Paulista Júlio de Mesquita Filho - UNESP, Jaboticabal, SP, Brasil
${ }^{2}$ Departamento de Clínica e Cirurgia Veterinária, Universidade Estadual Paulista Júlio de Mesquita Filho - UNESP, Jaboticabal, SP,
Brasil

Received April 15, 2019

Accepted July 04, 2019

\begin{abstract}
A free-living, adult male maned wolf (Chrysocyon brachyurus) was referred to the Governador "Laudo Natel" FCAV/Unesp veterinary hospital after being found with skin lesions and a fracture on the right pelvic limb, which had to be amputated due to compromised integrity. Around 20 days later, bilateral accentuated swollen on humerusradius-ulna articulation was observed. The synovial liquid was drained and sent to the laboratory for synovial cytology with Rosenfeld staining that revealed predominantly degenerated neutrophils with karyolytic chromatin associated with intracellular inclusions suggestive of Hepatozoon sp. gametocytes. Blood and synovial liquid samples were submitted to molecular analysis, aiming to amplify the Hepatozoon spp. $18 \mathrm{~S}$ rRNA gene fragment. Despite the positioning of the found Hepatozoon sequence together with Hepatozoon canis previously detected in domestic carnivores, the BLAST analysis showed only $98 \%$ identity with $H$. canis. To the best of the authors' knowledge, this is the first time a Hepatozoon was detected in the synovial liquid by clinical pathology and molecular analyses.
\end{abstract}

Keywords: Hepatozoonosis, cytopathology, gametocytes, wild canids.

\section{Resumo}

Um lobo guará (Chrysocyon brachyurus) adulto, macho, de vida livre foi encaminhado para atendimento no hospital veterinário Governador "Laudo Natel" - FCAV/Unesp após ser encontrado com lesóes de pele e fratura em membro pélvico direito, sendo amputado devido a comprometimento da integridade do membro. Aproximadamente 20 dias após a chegada ao hospital, foi notado acentuado aumento de volume bilateral em regiáo de articulação úmero-rádio-ulnar. O líquido sinovial foi drenado e enviado para análise citológica com coloração de Rosenfeld, revelando a presença de neutrófilos degenerados com cromatina cariolítica associados a inclusôes intracelulares sugestivas de gametócitos de Hepatozoon sp. Amostras de sangue e líquido sinovial foram submetidas a análises moleculares visando amplificar um fragmento do gene $18 \mathrm{~S}$ rRNA de Hepatozoon spp. Apesar da sequência de Hepatozoon detectada se posicionar filogeneticamente no mesmo clado que $H$. canis previamente detectado em carnívoros domésticos, o resultado da análise do BLAST mostrou somente 98\% de identidade com H. canis. De acordo com o conhecimento dos autores, esta é a primeira vez que Hepatozoon foi detectado no líquido sinovial por meio de patologia clínica e análises moleculares.

Palavras-chave: Hepatozoonose, citopatologia, gametócitos, canídeos selvagens.

\footnotetext{
*Corresponding author: Marcos Rogério André. Laboratório de Imunoparasitologia, Departamento de Patologia Veterinária, Faculdade de Ciências Agrárias e Veterinárias Júlio de Mesquita Filho - UNESP, Campus de Jaboticabal, Via de Acesso Prof. Paulo Donato Castellane, s/n, Zona Rural, CEP 14884-900, Jaboticabal, SP, Brasil. e-mail: marcosandre.fcav@gmail.com
} 


\section{Introduction}

The maned wolf (Chrysocyon brachyurus) is known as the largest wild canid species from South America, occurring in Argentina, Bolivia, Brazil, Paraguay, Peru, and Uruguay (DIETZ, 1984, 1985; RUMIZ \& SAINZ, 2002). Currently, the red list of the International Union for Conservation of Nature (IUCN) lists this species as "Near Threatened" (PAULA \& DEMATTEO, 2015). Diseases are a potential threat for wildlife conservation, but studies on the occurrence of pathogens in maned wolves are scarce (ANDRÉ et al., 2010; CURI et al., 2012; SILVEIRA et al., 2016). Regarding the occurrence of tick-borne agents, fewer studies have been performed.

Hepatozoon spp. are apicomplexan parasites that infect a wide variety of hosts, being described in domestic and wild mammals, birds, reptiles, and amphibians (SMITH, 1996; RAMOS et al., 2015). Domestic and wild canids can be infected with at least two Hepatozoon species, Hepatozoon canis and Hepatozoon americanum, which present distinct clinical signs, pathology, biology, and genetic characteristics (O'DWYER et al., 2011). Although Hepatozoon sp. infections in free-living animals are usually subclinical (KOCAN et al., 2000; METZGER et al., 2008), some studies have shown the occurrence of the clinical disease associated with $H$. americanum in coyotes (Canis latrans) in the United States (KOCAN et al., 2000) and mortality of hyenas (Crocuta crocuta) in Tanzania associated with a Hepatozoon sp. genetically distinct from the $H$. canis (EAST et al., 2008). These agents may play a role as potential opportunistic pathogens in immunocompromised animals or with concomitant diseases (BANETH et al., 2001; KUBO et al., 2006). Although several drugs have been proposed for treating the infection, there is no parasitological cure and, currently, no established treatment protocol for treating $H$. canis infection (SAKUMA et al., 2009). There are studies in the literature on treatments with either imidocarb dipropionate only or imidocarb dipropionate associated with doxycycline, toltrazuril, toltrazuril/emodepside, and clindamycin, but none of them proved to be efficient (SAKUMA et al., 2009; SASANELLI et al., 2010; PASA et al., 2011; TOMMASI et al., 2014).

Hepatozoon sp. was detected in the blood of one maned wolf by $18 \mathrm{Sr}$ RNA-based PCR for the first time in a Zoo in Sorocaba, southeastern Brazil (ANDRÉ et al., 2010). Interestingly, the found sequence clustered with other sequences detected in wild canids and felids, apart from the $H$. canis and $H$. americanum detected in domestic/wild canids (ANDRÉ et al., 2010). Infection by Hepatozoon sp. was also molecularly detected in a free-living, adult female maned wolf in Minas Gerais, southeastern Brazil. In this case, the found 18SrRNA sequence showed $98 \%$ identity to $H$. americanum (SILVEIRA et al., 2016). The present work aims to describe the clinical and laboratory findings of a maned wolf naturally infected by Hepatozoon sp. that was treated at a veterinary hospital in southeastern Brazil.

\section{Material and Methods}

\section{Clinical history}

An intact adult male maned wolf (Chrysocyon brachyurus), weighting $17 \mathrm{~kg}$ was referred to the Wildlife Medicine Service at the Veterinary Hospital of the Universidade Estadual "Julio de Mesquita Filho” (UNESP) (Jaboticabal, São Paulo, Brazil) after being found injured near the municipality of Barretos (Sao Paulo, southeastern Brazil). The patient was sedated with Ketamine $(8 \mathrm{mg} / \mathrm{kg}, \mathrm{IM})$ and Midazolam $(0.2 \mathrm{mg} / \mathrm{kg}, \mathrm{IM})$ for the clinical procedures. The clinical examination indicated pale mucous (oral and eyes), 163 beats/min heart rate, 36 breaths/min respiratory rate, $37.2^{\circ} \mathrm{C}$ rectal temperature, 3 s capillary refill time (CRT), and dehydration estimated in $8 \%$ while following complementary laboratory analysis showed $87 \mathrm{mg} / \mathrm{dL}$ glucose. Additionally, the right pelvic limb showed a severe bone and muscle damage compromising limb functionality and three wounds were found on the left pelvic limb. Even though a light tick infestation was observed, they were not sampled.

It was decided for the amputation of the right pelvic limb due to compromised limb integrity. One month after the procedure, it was noticed a swollen on both thoracic limbs near the humerus-radius-ulna articulation. The animal was sedated for physical examination, followed by a trichotomy of both thoracic limbs before synovial liquid sampling performed with a $0.8 \times 25 \mathrm{~mm}$ needle and $20 \mathrm{~mL}$ syringe to collect $50 \mathrm{~mL}$ and $22 \mathrm{~mL}$ aliquots from the right and left limbs, respectively. Liquid smears were fixed with methanol, stained with Rosenfeld and stored for molecular analyses. Blood smears were also prepared and stained with Fast Panoptic method $\left(\right.$ Laborclin $\left.^{\circledR}\right)$. The synovial liquid smear was entirely examined, including the feathered and lateral edges, readable and thick areas, under 40x objective. For blood smear analysis, the smear was first examined at the feathered edge for differential leukocyte count under 40x objective, and then scanned for hemoparasites at the feathered edge and monolayer under 100x objective. Additionally, at the day of synovial liquid sampling, the blood sample was also submitted to buffy coat smear analysis. After draining the synovial liquid, the animal was kept with a compressive bandage on both thoracic limbs medicated with meloxicam $(0.2 \mathrm{mg} / \mathrm{kg}$, IM, SID, for 3 days), nutritional conditions were improved and the cage was modified to shorten the decubitus period after the amputation procedure. Hematological analyses were performed during the entire hospital care.

\section{DNA extraction and molecular analyses}

DNA was extracted from $200 \mu \mathrm{L}$ whole blood with EDTA and from a $200 \mu \mathrm{L}$ synovial liquid using the DNeasy Blood \& Tissue Kit, according to manufacturer instructions. The $18 \mathrm{SrRNA}$ of Hepatozoon sp. was amplified based on the PCR protocol described by Ujvari et al. (2004) (targeting a 600 bp fragment). Hepatozoon sp. DNA obtained from a naturally infected Leptodactylus latrans was used as positive control (accession number MK503643). The PCR amplicon obtained from synovial liquid was purified using the Silica Bead DNA gel extraction kit 
(Thermo Fisher Scientific ${ }^{\circledR}$, Waltham, MA, USA). Sequencing was carried out using the BigDye ${ }^{\circledR}$ Terminator v3.1 Cycle Sequencing Kit (Thermo Fisher Scientific ${ }^{\circledR}$, Waltham, MA, USA) and ABI PRISM 310DNA Analyzer (Applied Biosystems ${ }^{\circledR}$, Foster City, CA, EUA) (SANGER et al., 1977). Electropherogram quality and a consensus sequence were obtained through analysis of the sense and antisense sequence using the Phred Phrap software (EWING \& GREEN, 1998). The identity values were assessed by BLASTn tool (using default parameters), available in the NCBI GenBank database (ALTSCHUL et al., 1990). Sequences deposited in the GenBank used for phylogenetic inferences were selected from BLAST results and from other studies performed in Brazil and in other countries. Maximum likelihood tree inference was performed with IQ-TREE software using TPM2+F+G evolutionary model (TRIFINOPOULOS et al., 2016). The phylogenetic tree edition and rooting were performed using the Treegraph 2.0 beta software (STOVER \& MULLER, 2010). The blood samples were also tested for the presence of DNA from other hemoparasites such as Babesia/Rangelia/Theileria targeting the 18SrRNA gene (JEFFERIES et al., 2007), and Mycoplasma sp. (MAGGI et al., 2013) and Anaplasmataceae agents (INOKUMA et al., 2000) targeting the $16 \mathrm{~S}$ rRNA gene.

\section{Results}

\section{Blood and synovial liquid smears}

No gamont suggestive of Hepatozoon spp. infection was observed in the blood smears. The pale red synovial liquid had a low viscosity while the cytology revealed the predominance of degenerate neutrophils with karyolytic chromatin associated with intracellular inclusions suggestive of Hepatozoon sp. (Figure 1). Additionally, pyogranulomatous inflammation and red blood cells (hemarthrosis) with loss of windrowing, which reflected the low viscosity of the fluid, were also observed.

\section{DNA extraction and molecular analyses}

Both blood and synovial liquid were positive for PCR targeting Hepatozoon sp.-18S rRNA. The $18 \mathrm{~S}$ rRNA sequence detected in synovial liquid was deposited in the GenBank (MK424119) while BLAST results showed $98 \%$ identity with $H$. canis sequences detected in wild and domestic canids in Brazil and other countries. The phylogenetic inference, estimated by Maximum Likelihood, clustered sequences in six branches: i.) the first group consisted of $H$. canis sequences detected in domestic carnivores and the maned wolf of this study; ii.) the second, $H$. canis sequences detected in domestic and wild canids; iii.) the third, $H$. procyonis, detected in coatis (Nasua nasua); iv.) H. felis and Hepatozoon spp. detected in domestic and wild felids; v.) H. americanum and Hepatozoon spp. detected in domestic and wild canids; vi.) Hepatozoon sp. detected in rodents and reptiles (Figure 2). The clades showed considerable statistical support. Haemogregarina spp. sequences were used as outgroups.

The maned wolf was negative for piroplasmids, hemoplasmas, and Anaplasmataceae agents according the to results of the PCR assays.

\section{Discussion}

Infection caused by $H$. canis may be often a subclinical disease, usually associated with low parasitemia, but in some cases, $H$. canis infection can lead to severe disease that includes muscle lesions, anorexia, weight loss, pale mucous membranes and other clinical sings (BANETH \& WEIGLER, 1997; PALUDO et al., 2005). Animals with severe disease symptoms have been shown to have extreme neutrophilia and high levels of parasitemia (BANETH; SHKAP, 2003). H. canis were detected in three Brazilian dogs with persistent parasitemia, causing muscle degeneration and atrophy, and degenerating/regenerating myofibers, similar to the muscle degeneration caused by $H$. americanum (PALUDO et al., 2005). Although no gametocyte was observed in the peripheral blood

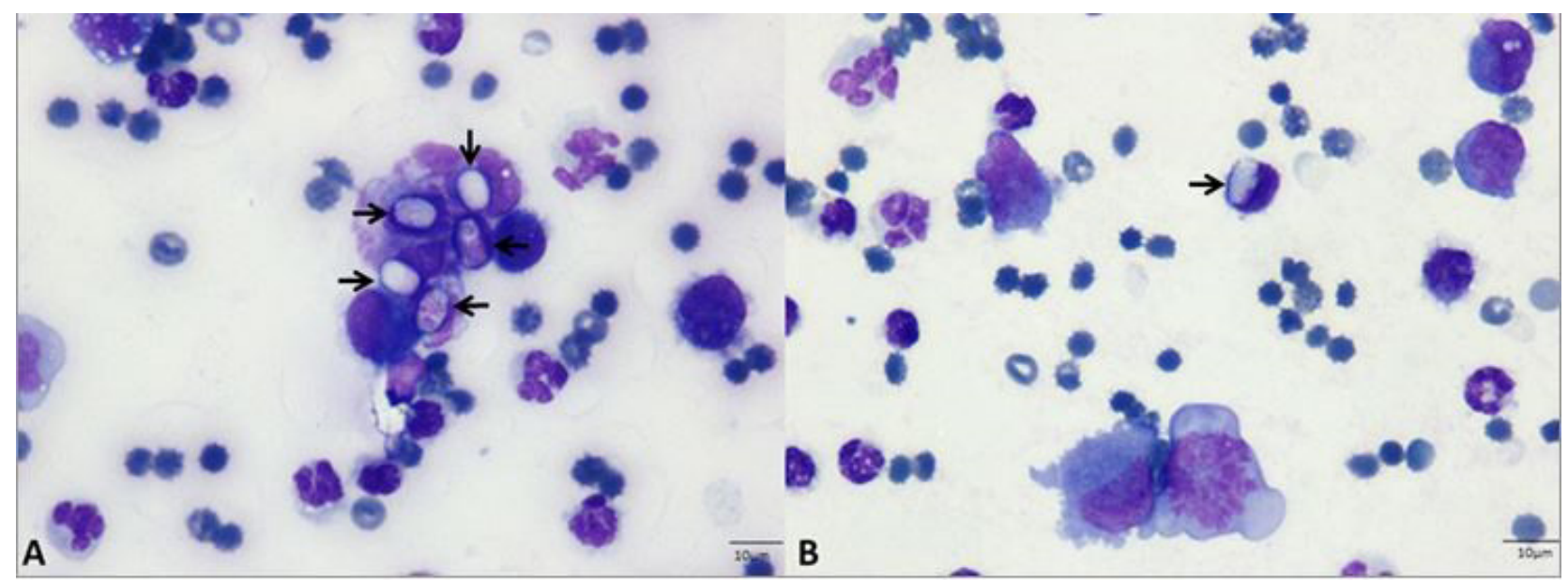

Figure 1. Synovial liquid smear stained with Rosenfeld (100x obj.). (A) Degenerate neutrophils with karyolytic chromatin associated with intracellular inclusions suggestive of Hepatozoon sp. gametocytes (arrow); (B) Pyogranulomatous inflammation, red blood cells (hemarthrosis) with loss of windrowing and intracellular inclusions suggestive of Hepatozoon sp. gametocytes (arrow). 


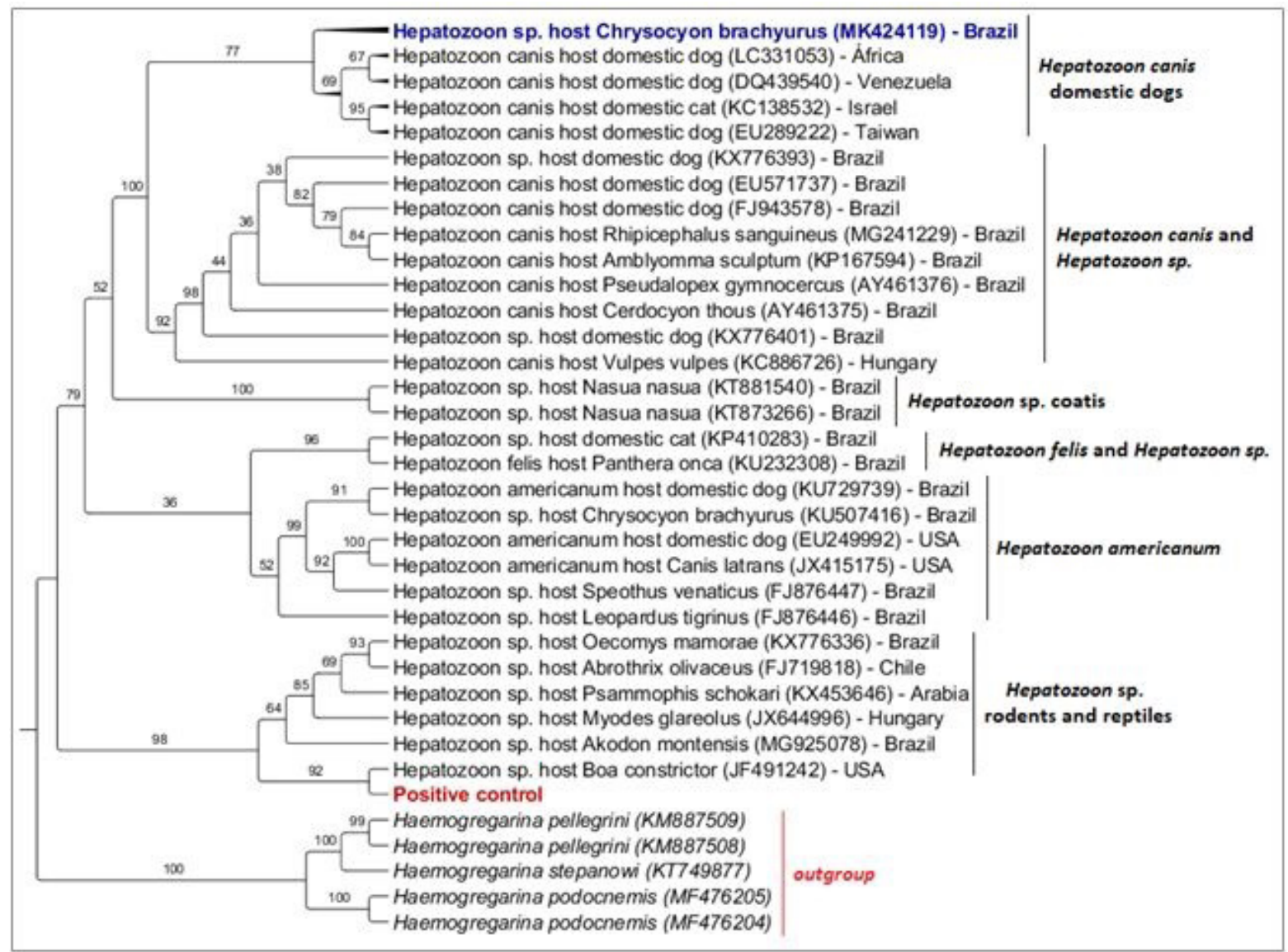

Figure 2. Phylogenetic tree based on the $600 \mathrm{bp}$ fragment (UJVARI et al., 2004) of Hepatozoon spp. 18SrRNA sequences, using the Maximum likelihood inference (ML) method and TPM2+F+G evolutionary model. Numbers at nodes correspond to bootstrap. Accession numbers are indicated in the sequences. The sequence of Hepatozoon spp. detected in the present study is highlighted in blue. The positive control is highlighted in red.

smears, the maned wolf from this study presented neutrophilia with toxic granules, which probably resulted from the infected skin lesions and limb injury, with no relation with Hepatozoon infection. After 59 days, the animal did not present leukocytosis anymore, which indicated that the neutrophilia was associated with bacterial infection, which was resolved after antibiotic therapy. At the day of discharge from hospital (3 months after the entrance of the animal at the Veterinary Hospital), the animal was still positive for Hepatozoon spp. by PCR, which shows that the neutrophilia was not associated with Hepatozoon infection.

The swollen on both thoracic limbs, near the humerous-radius-ulna articulation, allowed the detection of Hepatozoon gamonts in synovial liquid smears. In fact, the observed swollen might have been the result of an extensive period of decubitus that the animal showed after the amputation procedure. Results of synovial liquid cytology indicated inflammation, which may have resulted in migration of leukocytes to the region. It is most likely that the migration of leucocytes to humerous-radius-ulna articulation generated an increase of the presence of neutrophils in the area, which in association with immunosuppression due to anesthesia/hospitalization procedures, allowed the detection of
Hepatozoon gamonts. It is known that immunosuppression caused by concomitant infections or immunosuppressive medications may influence the pathogenesis of new infection by $H$. canis or reactivate an existing infection (BANETH et al., 2001).

Unlike other tick-borne diseases, hepatozoonosis is transmitted by ingestion of ticks by the intermediary host (BANETH \& SHKAP, 2003). In tropical and subtropical regions, including Brazil and the United States, studies showed that $H$. canis is transmitted by Amblyomma ovale ticks, Haemaphysalis longicornis, Haemaphysalis flava, and Rhipicephalus sanguineus sensu lato (MURATA et al., 1995; FORLANO et al., 2005, 2007; RUBINI et al., 2009). In Brazil, the participation of $R$. sanguineus s.l. in the transmission of $H$. canis should be better investigated (GOMES et al., 2016). The maned wolf from this report had a light infestation of ticks, which, unfortunately, were not sampled. To understand better the transmission of hepatozoonosis and other hemoparasites, ectoparasites should always be sampled and identified, and molecular analyses should be performed to identify possible pathogens.

Studies in the literature have reported that $H$. canis has been commonly detected in domestic dogs from all Brazilian regions (RUBINI et al., 2008; SPOLIDORIO et al., 2009; RAMOS et al., 
2010, 2015; SOUSA et al., 2017). Hepatozoon phylogenetically related to $H$. americanum has been recently described in domestic dogs in Belém, northern Brazil (GOMES et al., 2016), while both Hepatozoon species have been detected in wild canids from Brazil. While Hepatozoon sp. related to H. americanum has been detected in maned wolf and crab-eating fox (Cerdocyon thous) (CRIADO-FORNELIO et al., 2006; ANDRÉ et al., 2010; SOUSA et al., 2017), H. canis was detected in Cerdocyon thous and Pampas fox (Lycalopex gymnocercus) (CRIADO-FORNELIO et al., 2006; SILVA et al., 2018). Additionally, a possible new Hepatozoon species that clustered separately from $H$. canis and $H$. americanum based on 18S rRNA phylogenetic inference has been detected in maned wolf, bush dog (Speothus venaticus) and hoary fox (Pseudalopex vetulus) maintained in captivity in Brazil (ANDRÉ et al., 2010). In this study, the molecular and phylogenetic analyses of the Hepatozoon-18SrRNA sequence found in the synovial liquid from the maned wolf clustered with $H$. canis sequences detected only in domestic carnivores. The increased contact between wild and domestic canids in disturbed environments may facilitate pathogen exchanges, constituting one of the main threats against the maned wolf populations (PAULA et al., 2013; OROZCO et al., 2013). The animal evaluated in this report was found on a road, near a peri-urban area, and its presence in such an area may have facilitated contact with domestic animals and infection by $H$. canis. Although clustering with $H$. canis sequences, the amplified sequences showed only $98 \%$ of identity with $H$. canis by BLAST analysis, which may suggest that the maned wolf was infected with another closely related Hepatozoon species. Considering that the $18 \mathrm{~S}$ rDNA gene has been the only molecular marker used for phylogenetic analyses of Hepatozoon spp. so far, problems for discriminating closely related species might occur due to its high degree of conservation (MORRISON et al., 2004). Recently, the complete genome of $H$. canis was sequenced, which may allow the use of new target genes, aiming ate achieving better discrimination of Hepatozoon species (LÉVEILLÉ et al., 2019).

The Hepatozoon sp. epidemiology in wild canids in Brazil has not been fully elucidated yet. Although not producing the clinical disease, Brazilian wild canids apparently have subclinical canine hepatozoonosis, which may be aggravated when associated with other parasites. For instance, Silva et al. (2018) detected co-infection between Rangelia vitalii and $H$. canis in a free-living L. gymnocercus from the state of Santa Catarina, southern Brazil. Quadros et al. (2015) also reported the co-infection by $R$. vitalii, H. canis, and Capillaria hepatica in an L. gymnocercus specimen, which developed a fatal illness, in the state of Santa Catarina. In Minas Gerais, southeastern Brazil, Silveira et al. (2016) reported the co-infection by $R$. vitalii, Hepatozoon sp., Leishmania sp., Entamoeba spp. and intestinal helminths in a maned wolf. In the present case report, co-infections by piroplasmids, hemoplasmas, and Anaplasmataceae agents were not found.

\section{Conclusion}

To the best of authors' knowledge, this is the first report of Hepatozoon sp. gametocytes in synovial liquid of a maned wolf. Although clustering with $H$. canis previously detected in domestic carnivores in phylogenetic analyses, BLAST results may indicate that the maned wolf was infected with another closely related Hepatozoon species. Keeping in mind that an increase contact between wild and domestic animals may facilitate pathogen exchange, special attention should be given for vector-borne agents in endangered wild carnivores maintained in captivity.

\section{Acknowledgements}

We are thankful to "Fundação de Amparo à Pesquisa do Estado de São Paulo” (FAPESP) for the financial support (Process \#2018/02753-0) and "Conselho Nacional de Desenvolvimento Científico e Tecnológico” (CNPq - Research Productivity Scholarship - Process number 302420/2017-7) for Researcher Fellowship delivered to MRA.

\section{References}

Altschul SF, Gish W, Miller W, Myers EW, Lipman DJ. Basic local alignment search tool. J Mol Biol 1990; 215(3): 403-410. http://dx.doi. org/10.1016/S0022-2836(05)80360-2. PMid:2231712.

André MR, Adania CH, Teixeira RHF, Vargas GH, Falcade M, Sousa $\mathrm{L}$, et al. Molecular detection of Hepatozoon spp. in Brazilian and exotic wild carnivores. Vet Parasitol 2010; 173(1-2): 134-138. http://dx.doi. org/10.1016/j.vetpar.2010.06.014. PMid:20630658.

Baneth G, Samish M, Alekseev E, Aroch I, Shkap V. Transmission of Hepatozoon canis to dogs by naturally-fed or percutaneously-injected Rhipicephalus sanguineus ticks. J Parasitol 2001; 87(3): 606-611. http:// dx.doi.org/10.1645/0022-3395(2001)087[0606:TOHCTD]2.0.CO;2. PMid:11426725.

Baneth G, Shkap V. Monozoic cysts of Hepatozoon canis. J Parasitol 2003; 89(2): 379-381. http://dx.doi.org/10.1645/0022-3395(2003)089[0379:MC OHC]2.0.CO;2. PMid:12760658.

Baneth G, Weigler B. Retrospective case-control study of hepatozoonosis in dogs in Israel. J Vet Intern Med 1997; 11(6): 365-370. http://dx.doi. org/10.1111/j.1939-1676.1997.tb00482.x. PMid:9470163.

Criado-Fornelio A, Ruas JL, Casado N, Farias NA, Soares MP, Müller $\mathrm{G}$, et al. New molecular data on mammalian Hepatozoon species (Apicomplexa: Adeleorina) from Brazil and Spain. J Parasitol 2006; 92(1): 93-99. http://dx.doi.org/10.1645/GE-464R.1. PMid:16629322.

Curi NHA, Coelho CM, Campo MCM, Magni EM, Sábato MA, Araújo AS, et al. Pathogens of Wild Maned Wolves (Chrysocyon brachyurus) in Brazil. J Wildl Dis 2012; 48(4): 1052-1056. http://dx.doi.org/10.7589/201110-304. PMid:23060508.

Dietz JM. Ecology and social organization of maned wolf (Chrysocyon brachyurus). Washington: Smithsonian Institution Press; 1984. (Smithsonian Contributions to Zoology; no. 392). https://doi.org/10.5479/ si.00810282.392.

Dietz JM. Chrysocyon brachyurus. Mamm Species 1985; 234(234): 1-4. http://dx.doi.org/10.2307/3503796.

East ML, Wibbelt G, Lieckfeldt D, Ludwig A, Goller K, Wilhelm K, et al. A Hepatozoon species genetically distinct from $H$. canis infecting spotted hyenas in the Serengeti ecosystem, Tanzania. J Wildl Dis 2008; 44(1): 45-52. http://dx.doi.org/10.7589/0090-3558-44.1.45. PMid:18263820. 
Ewing B, Green P. Base-calling of automated sequencer traces using phred. II. Error probabilities. Genome Res 1998; 8(3): 186-194. http:// dx.doi.org/10.1101/gr.8.3.186. PMid:9521922.

Forlano M, Scofield A, Elisei C, Fernandes KR, Ewing SA, Massard CL. Diagnosis of Hepatozoon spp. in Amblyomma ovale and its experimental transmission in domestic dogs in Brazil. Vet Parasitol 2005; 134(1-2): 1-7. http://dx.doi.org/10.1016/j.vetpar.2005.05.066. PMid:16081219.

Forlano M, Teixeira KRS, Scofield A, Elisei C, Yotoko KS, Fernandes $\mathrm{KR}$, et al. Molecular characterization of Hepatozoon sp. from Brazilian dogs and its phylogenetic relationship with other Hepatozoon spp. Vet Parasitol 2007; 145(1-2): 21-30. http://dx.doi.org/10.1016/j.vetpar.2006.10.023. PMid:17134837.

Gomes LA, Moraes PHG, Nascimento LCS, O’Dwyer LH, Nunes MRT, Rossi ARP, et al. Molecular analysis reveals the diversity of Hepatozoon species naturally infecting domestic dogs in a northern region of Brazil. Ticks Tick Borne Dis 2016; 7(6): 1061-1066. http://dx.doi.org/10.1016/j. ttbdis.2016.09.008. PMid:27665264.

Inokuma H, Raoult D, Brouqui P. Detection of Ehrlichia platys DNA in brown dog ticks (Rhipicephalus sanguineus) in Okinawa Island, Japan. $J$ Clin Microbiol 2000; 38(11): 4219-4221. PMid:11060094.

Jefferies R, Ryan UM, Irwin PJ. PCR-RFLP for the detection and differentiation of the canine piroplasm species and its use with filter paper-based technologies. Vet Parasitol 2007; 144(1-2): 20-27. http:// dx.doi.org/10.1016/j.vetpar.2006.09.022. PMid:17127005.

Kocan AA, Cummings CA, Panciera RJ, Mathew JS, Ewing SA, Barker RW. Naturally occurring and experimentally transmitted Hepatozoon americanum in coyotes from Oklahoma. J Wildl Dis 2000; 36(1): 149153. http://dx.doi.org/10.7589/0090-3558-36.1.149. PMid:10682757.

Kubo M, Miyoshi N, Yasuda N. Hepatozoonosis in two species of Japanese wild cat. J Vet Med Sci 2006; 68(8): 833-837. http://dx.doi.org/10.1292/ jvms.68.833. PMid:16953084.

Léveillé AN, Baneth G, Barta JR. Next generation sequencing from Hepatozoon canis (Apicomplexa: Coccidia: Adeleorina): complete apicoplast genome and multiple mitochondrion-associated sequences. Int J Parasitol 2019; 49(5): 375-387. http://dx.doi.org/10.1016/j.ijpara.2018.12.001. PMid:30790556.

Maggi RG, Mascarelli PE, Havenga LN, Naidoo V, Breitschwerdt EB. Co-infection with Anaplasma platys, Bartonella henselae and Candidatus Mycoplasma haematoparvum in a veterinarian. Parasit Vectors 2013; 6(1): 103. http://dx.doi.org/10.1186/1756-3305-6-103. PMid:23587235.

Metzger B, Paduan KS, Rubini AS, Oliveira TG, Pereira C, O’Dwyer LH. The first report of Hepatozoon sp. (Apicomplexa: Hepatozoidae) in neotropical felids from Brazil. Vet Parasitol 2008; 152(1-2): 28-33. http:// dx.doi.org/10.1016/j.vetpar.2007.12.006. PMid:18243562.

Morrison DA, Bornstein S, Thebo P, Wernery U, Kinne J, Mattsson JG. The current status of the small subunit rRNA phylogeny of the coccidia (Sporozoa). Int J Parasitol 2004; 34(4): 501-514. http://dx.doi. org/10.1016/j.ijpara.2003.11.006. PMid:15013740.

Murata T, Inoue M, Taura Y, Nakama S, Abe H, Fujisaki K. Detection of Hepatozoon canis oocyst from ticks collected from the infected dogs. J Vet Med Sci 1995; 57(1): 111-112. http://dx.doi.org/10.1292/jvms.57.111. PMid:7756400.

O’Dwyer LH, Saito ME, Hasegawa MY, Kohayagawa A. Brazilian canine hepatozoonosis. Rev Bras Parasitol Vet 2011; 20(3): 181-193. http:// dx.doi.org/10.1590/S1984-29612011000300002. PMid:21961746.
Orozco M, Ceballos LA, Pino MC, Gurtler RE. Local threats and potential infectious hazards to maned wolves (Chrysocyon brachyurus) in the southeastern Argentine Chaco. Mammalia 2013; 78(3): 339-349. http://dx.doi.org/10.1515/mammalia-2013-0067.

Paludo GR, Friedmann H, Dell'Porto A, Macintire DK, Whitley EM, Boudreaux MK, et al. Hepatozoon spp.: pathological and partial 18S rRNA sequence analysis from three Brazilian dogs. Parasitol Res 2005; 97(2): 167 170. http://dx.doi.org/10.1007/s00436-005-1419-2. PMid:15988602.

Pasa S, Voyvoda H, Karagenc T, Atasoy A, Gazyagci S. Failure of combination therapy with imidorcarb dipropionate and toltrazuril to clear Hepatozoon canis infection in dogs. Parasitol Res 2011; 109(3): 919926. http://dx.doi.org/10.1007/s00436-011-2334-3. PMid:21472405.

Paula RC, DeMatteo K. Chrysocyon brachyurus, Maned Wolf. USA: International Union for Conservation of Nature and Natural Resources; 2015. The IUCN Red List of Threatened Species. http://dx.doi.org/10.2305/ IUCN.UK.2015-4.RLTS.T4819A82316878.en

Paula RC, Rodrigues FHG, Queirolo D, Jorge RPS, Lemos FG, Almeida Rodrigues L. Avaliação do estado de conservação do Lobo-guará Chrysocyon brachyurus (Illiger, 1815) no Brasil. Biodiver Bras 2013; 3: 146-159.

Quadros RM, Soares JF, Xavier JS, Pilati C, Costa JL, Miotto BA, et al. Natural Infection of the Wild Canid Lycalopex gymnocercus by the Protozoan Rangelia vitalii, the Agent of Canine Rangeliosis. JWildl Dis 2015; 51(3): 787-789. http://dx.doi.org/10.7589/2014-08-194. PMid:25932667.

Ramos CAN, Babo-Terra VJ, Pedroso TC, Souza AF Fo, Araújo FR, Cleveland HPK. Molecular identification of Hepatozoon canis in dogs from Campo Grande, Mato Grosso do Sul, Brazil. Rev Bras Parasitol Vet 2015; 24(2): 247-250. http://dx.doi.org/10.1590/S1984-29612015019. PMid:26154969.

Ramos R, Ramos C, Araújo F, Oliveira R, Souza I, Pimentel D, et al. Molecular survey and genetic characterization of tick-borne pathogens in dogs in metropolitan Recife (north-eastern Brazil). Parasitol Res 2010 107(5): 1115-1120. http://dx.doi.org/10.1007/s00436-010-1979-7. PMid:20680344.

Rubini AS, Paduan KS, Martins TF, Labruna MB, O’Dwyer LH. Acquisition and transmission of Hepatozoon canis (Apicomplexa: Hepatozoidae) by the tick Amblyomma ovale (Acari: Ixodidae). Vet Parasitol 2009; 164(2-4):324327. http://dx.doi.org/10.1016/j.vetpar.2009.05.009. PMid:19501969.

Rubini AS, Paduan KS, Von Ah Lopes V, O’Dwyer LH. Molecular and parasitological survey of Hepatozoon canis (Apicomplexa: Hepatozoidae) in dogs from rural area of Sao Paulo state, Brazil. Parasitol Res 2008; 102(5): 895-899. http://dx.doi.org/10.1007/s00436-007-0846-7. PMid:18188597.

Rumiz D, Sainz LA. Estimación del hábitat útil y la abundancia potencial del lobo de crin o borochi (Chrysocyon brachyurus) em Huanchaca, Santa Cruz - Bolivia. Rev Bol Ecol 2002; 11: 3-16.

Sakuma M, Nakahara Y, Suzuki H, Uchimura M, Sekiya Z, Setoguchi A, et al. A case report: a dog with acute onset of Hepatozoon canis infection.J Vet Med Sci 2009; 71(6): 835-838. http://dx.doi.org/10.1292/ jvms.71.835. PMid:19578300.

Sanger F, Nicklen S, Coulson AR. DNA sequencing with chain-terminating inhibitors. Proc Natl Acad Sci USA 1977; 74(12): 5463-5467. http:// dx.doi.org/10.1073/pnas.74.12.5463. PMid:271968.

Sasanelli M, Paradies P, Greco B, Eyal O, Zaza V, Baneth G. Failure of imidocarb diproprionate to eliminate Hepatozoon canis in naturally infected dogs based on parasitological and molecular evaluation methods. Vet Parasitol 2010; 171(3-4): 194-199. http://dx.doi.org/10.1016/j. vetpar.2010.03.042. PMid:20444549. 
Silva MRL, Mattoso CRS, Costa A, Saito ME, Tchaicka L, O’Dwyer LH. Rangelia vitalii and Hepatozoon canis coinfection in pampas fox Lycalopex gymnocercus from Santa Catarina State, Brazil. Rev Bras Parasitol Vet 2018; 27(3): 377-383. http://dx.doi.org/10.1590/s1984-296120180018. PMid:29846457.

Silveira JA, D’Elia ML, Oliveira Avelar I, Almeida LR, Santos HÁ, Soares DFM, et al. Rangelia vitalii in a free-ranging maned wolf (Chrysocyon brachyurus) and co-infections. Int J Parasitol Parasites Wildl 2016; 5(3): 280285. http://dx.doi.org/10.1016/j.ijppaw.2016.09.003. PMid:27761403.

Smith TG. The genus Hepatozoon (Apicomplexa: adeleina). J Parasitol 1996; 82(4): 565-585. http://dx.doi.org/10.2307/3283781. PMid:8691364.

Sousa KCM, Fernandes MP, Herrera HM, Benevenute JL, Santos FM, Rocha FL, et al. Molecular detection of Hepatozoon spp.in domestic dogs and wild mammals in southern Pantanal, Brazil with implications in the transmission route. Vet Parasitol 2017; 237: 37-46. http://dx.doi. org/10.1016/j.vetpar.2017.02.023. PMid:28291601.

Spolidorio MG, Labruna MB, Zago AM, Donatele DM, Caliari KM, Yoshinari NH. Hepatozoon canis infecting dogs in the state of Espírito
Santo, southeastern Brazil. Vet Parasitol 2009; 163(4): 357-361. http:// dx.doi.org/10.1016/j.vetpar.2009.05.002. PMid:19482427.

Stover BC, Muller KF. TreeGraph 2: combining and visualizing evidence from different phylogenetic analyses. BMC Bioinformatics 2010; 11(1): 7. http://dx.doi.org/10.1186/1471-2105-11-7. PMid:20051126.

Tommasi AS, Giannelli A, Caprariis D, Ramos RAN, di Paola G, Crescenzo G, et al. Failure of imidocarb dipropionate and toltrazuril/ emodepside plus clindamycin in treating Hepatozoon canis infection. Vet Parasitol 2014; 200(3-4): 242-245. http://dx.doi.org/10.1016/j. vetpar.2013.12.013. PMid:24439769.

Trifinopoulos J, Nguyen LT, von Haeseler A, Minh BQ. W-IQ-TREE: a fast online phylogenetic tool for maximum likelihood analysis. Nucleic Acids Res 2016; 44(W1): W232-235. http://dx.doi.org/10.1093/nar/ gkw256. PMid:27084950.

Ujvari B, Madsen T, Olsson M. High prevalence of Hepatozoon spp. (Apicomplexa, Hepatozoidae) infection in water pythons (Liasis fuscus) from tropical Australia. J Parasitol 2004; 90(3): 670-672. http://dx.doi. org/10.1645/GE-204R. PMid:15270125. 